\title{
Perceived risk modifies the effect of HIV knowledge on sexual risk behaviors
}

\section{Gholamhossein Noroozinejad' ${ }^{1}$ Mosaieb Yarmohmmadi Vasel ${ }^{2}$, Fatemeh Bazrafkan $^{3}$, Mahmoud Sehat $^{4}$, Majid Rezazadeh ${ }^{5}$ and Khodabakhsh Ahmadi ${ }^{6}$ *}

\author{
${ }_{1}^{1}$ Faculty of Medicine, Qom University of Medical Sciences, Qom, Iran \\ ${ }^{2}$ Department of Psychology, Bu-Ali Sina University, Hamedan, Iran \\ ${ }^{3}$ Universal Network for Health Information Dissemination and Exchange (UNHIDE), Tehran, Iran \\ ${ }^{4}$ Medicine and Health Promotion Institute, Tehran, Iran \\ ${ }^{5}$ AIDS Prevention and Control Committee, Welfare Organization State, Tehran, Iran \\ ${ }^{6}$ Behavioral Sciences Research Center, Baqiyatallah Medical Sciences University, Tehran, Iran
}

Edited by:

Shervin Assari, School of Public Health, University of Michigan,

Ann Arbor, USA

\section{Reviewed by:}

Katayoon Khushabi, University of

Social Welfare and Rehabilitation

Science, Iran

Hooman Angoorani, Tehran University, Iran

\section{*Correspondence:}

Khodabakhsh Ahmadi, Baqiyatallah University of Medical Sciences, Mollasadra Street, 19945-546, Tehran, Iran

e-mail: khodabakhsh.ahmadi@ gmail.com
Background: There is a large controversy in the literature about the inter-relations between perceived risk, knowledge, and risk behavior in different settings, and people at HIV risk are not an exception.

Aim: To assess additive and multiplicative effect of perceived HIV risk and HIV knowledge on sexual risk behavior of Injecting Drug Users (IDUs).

Method: We enrolled 162 street based IDUs to this analysis. Data came from a national survey of IDUs in Iran, with a cross sectional design. Socio-demographics (employment, education, marital status), HIV knowledge, perceived HIV risk, and four different sexual risk behavior were registered. In the first step, using spearman test, the association of HIV knowledge and risk behavior were tested, then possible moderating effect of perceived HIV risk on this association was determined.

Results: Although among IDUs with low perceived HIV risk, HIV knowledge was negatively associated with sexual risk behavior $(P<0.05$ for all), this association was not significant among IDUs with high perceived HIV risk ( $P>0.05$ for all). Thus perceived HIV risk moderated the association between HIV knowledge and sexual risk behavior.

Conclusion: Perceived risk should be taken into consideration when studying the effect of HIV knowledge on sexual risk behavior of IDUs. Findings may help us better understand negative effects of fear arousing interventions as a part of HIV prevention media campaigns.

Keywords: HIV knowledge, perceived risk, sexual risk behavior, moderator, interaction effect

\section{INTRODUCTION}

Although some studies don't agree with the statement that a high level of knowledge is important in obtaining modifications in high-risk behavior (1), other studies stress the relevance of information in achieving effective control over behavior $(2,3)$.

Health Belief Model (HBM) has provided important insights to predict human behaviors. A recurrent theme in HBM theory is the role of perception about risk and benefits associated with a behavior as an antecedent of behavior $(1,4-8)$. It is possible, however, that the lack of consistent findings regarding knowledge as a significant antecedent of behavior has occurred because an important (factor, influential factor) has been overlooked. According to this model, high perceived risk of harm should encourage people to take action to reduce their risk. Although this implied positive relation between perceived risk and subsequent protective behavior is observed in many empirical studies, it is often weaker than expected (9). Some studies, however, have found no association or even a negative one $(1,10)$. Our hypothesis is that contradictions observed in the results might be due to ignoring the intensity of perceived risk.
There are considerable research attempting to understand how people perceive risks, the accuracy of their perception of these risk $(11,12)$, and role of perceived risk as a determinant of behavior or its change $(13,14)$. There are also some studies that investigate the association between knowledge and behavior $(15,16)$, however, based on our knowledge, there is not much studies assessing the association between knowledge and behavior by considering level of perceived risk as a possible moderator (17).

Designing public health risk communication programs to persuade people to avoid risk-reducing action requires a detailed knowledge about the pattern of influence of these programs and how can maximize this effect.

\section{MATERIALS AND METHODS DESIGN AND SETTING}

This cross sectional study conducted on 162 injecting drug users (IDUs) sampled from streets in eight provinces located in various different geographical parts of Iran: Tehran, Shiraz, Esfahan, Arak, Ahvaz, Rasht, Mashhad, and Ardebil. The study was conducted 
by Behavioral Sciences Research Center, Baqiyatallah University of Medical Sciences during 2009.

\section{CODES OF ETHICS}

The study was approved by the ethical review committee of the Baqiyatallah University of medical science. Participation was voluntary, and informed consent was gained from all participants. Purpose of the study was explained to each participant before his or her consent was sought. Participants were also assured of confidentiality and informed about their right to withdraw from the study at any time. Data was gathered anonymously.

\section{PARTICIPANTS AND SAMPLING}

Participants were all IDUs recruited from streets in the above listed cities by snowball sampling over a 7 months period in 2009. Every participant who reported positive history of drug injection during his life-time was considered as IDU. The study did not have any exclusion criteria.

\section{PROCESS}

Structured interviews were conducted by university-trained research assistants. Each interview lasted up to $60 \mathrm{~min}$. No financial incentives were offered to the participants.

\section{MEASURES}

Socio-demographic data (including marital status, educational level, and occupational situation), HIV knowledge (10 items including condom use, sex with a healthy looking person, HIV transmission routs), and perceived HIV risk (5 item Likert scale) was determined.

\section{MAIN OUTCOME}

Our questionnaire included the following four items to assess sexual risk behavior: During the past 6 months, how many times have you had condom-less sexual relationship with a person who was drug injector? During the past month, with how many people have you had sexual relationship? During the past month, totally how many times have you had condom-less sexual relationship?, and During the past month, how many times had you sex with an Illicit drug user?

\section{STATISTICAL ANALYSIS}

Data analysis was conducted in the Statistical Package for the Social Sciences 17 (SPSS Inc., IL, USA) for Windows. According to perceived risk, participants were entered in one of the following groups: high perceived risk (very high/high) and low perceived risk (moderate, low, very low). Spearman's test was applied to evaluate the correlation between level of knowledge and level of sexual risk behaviors in each stratum. Based on Baron and Kenny a moderator was defined as a variable affecting the direction and/or magnitude of an association between an independent (predictor) and a dependent (outcome) outcome (18). $P<0.05$ was considered significant.

\section{RESULTS}

From the 162 IDUs recruited to this study, 90 participants were categorized as having low perceived HIV risk, while 72 participants were considered to have high perceived HIV risk. In low perceived risk group, 50\% were single, 93\% had at least primary education, and $43 \%$ were unemployed. Among high perceived HIV risk IDUs, 55\% were single, $90 \%$ had at least primary education, and $37 \%$ were unemployed. There was no significant difference in comparison of socio-economics between these groups (Table 1).

Among IDUs with high perceived HIV risk, HIV knowledge was not associated with sexual risk behavior $(P>0.05$ for all correlations). Among IDUs with low perceived HIV risk, high level of HIV knowledge was associated with lower levels of sexual risk behavior ( $P<0.05$ in all correlations) (Table 2$)$.

\section{DISCUSSION}

Current study aimed to assess additive and multiplicative effect of perceived risk and HIV knowledge on sexual risk behavior among IDUs. This study showed a multiplicative effect of perceived risk and HIV knowledge on sexual risk behavior of IDUs. That said, higher HIV knowledge had no association with lower sexual risky behaviors in IDUs with high/very high levels of perceived HIV risk, however this association was found among IDUs who had very low to moderate levels of perceived HIV risk.

In this paper, perceived HIV risk was conceptualized as a buffer and HIV knowledge as a protective factor and sexual risk behaviors as outcome. In other words, the relationship between level of HIV knowledge and sexual risk behavior among IDUs may depend on level of perceived risk.

A study by Braithwaite showed no relationship between HIV/AIDS knowledge and generalized sexual risk-taking

Table 1 | Socio-demographic data among 162 Iranian IDUs.

\begin{tabular}{|c|c|c|c|c|}
\hline & \multicolumn{4}{|c|}{ Perceived HIV risk } \\
\hline & \multicolumn{2}{|c|}{ High } & \multicolumn{2}{|c|}{ Low } \\
\hline & $n$ & $\%$ & $n$ & $\%$ \\
\hline \multicolumn{5}{|l|}{ MARITAL STATUS } \\
\hline Single & 40 & 55.6 & 45 & 50 \\
\hline Married & 27 & 37.5 & 45 & 50 \\
\hline \multicolumn{5}{|l|}{ EDUCATIONAL LEVEL } \\
\hline Illiterate & 7 & 9.7 & 13 & 14.4 \\
\hline Primary school & 18 & 25 & 21 & 23.3 \\
\hline Some secondary school & 26 & 36.1 & 40 & 44.4 \\
\hline High school diploma & 11 & 15.3 & 7 & 7.8 \\
\hline Associated degree & 6 & 8.3 & 8 & 8.9 \\
\hline Bachelor's degree and higher & 2 & 2.8 & 1 & 1.1 \\
\hline \multicolumn{5}{|l|}{ OCCUPATION STATUS } \\
\hline Student & 0 & 0 & 1 & 1.1 \\
\hline Self-employe & 26 & 36.1 & 28 & 31.1 \\
\hline Employe & 2 & 2.8 & 2 & 2.2 \\
\hline Retired & 0 & 0 & 1 & 1.1 \\
\hline Home maker & 3 & 4.2 & 6 & 6.0 \\
\hline Work at private composite & 5 & 6.9 & 7 & 7.8 \\
\hline Unemployed & 27 & 37.5 & 39 & 43.3 \\
\hline
\end{tabular}

There was no significant difference between the two groups in any of the variables. Chi square. 
Table 2 | Correlation between HIV knowledge and sexual risk behavior among Iranian IDUs with low versus high perceived HIV risk.

\begin{tabular}{|c|c|c|c|c|}
\hline & \multicolumn{4}{|c|}{ Perceived HIV risk } \\
\hline & \multicolumn{2}{|c|}{ High } & \multicolumn{2}{|c|}{ Low } \\
\hline & $\begin{array}{l}\text { Correlation } \\
\text { coefficient }\end{array}$ & $P$ value & $\begin{array}{l}\text { Correlation } \\
\text { coefficient }\end{array}$ & $P$ value \\
\hline Number of condom-less sexual relations with a drug injector during the past 6 months & 0.232 & 0.056 & 0.366 & 0.005 \\
\hline Number of sexual partners during the previous months & -0.175 & 0.201 & -0.334 & 0.017 \\
\hline Number of condom-less sexual relations during the past months & -0.156 & 0.219 & 0.285 & 0.03 \\
\hline Number of sexual relations with an illicit drug user during the past months & -0.122 & 0.353 & 0.318 & 0.02 \\
\hline
\end{tabular}

behaviors (19). The absence of such a relationship was implied that knowledge about risk does not necessarily translate into protective behaviors. These findings were also consistent with a study by Salgado de Snyder et al. (20) demonstrating that while women had information regarding means of HIV/AIDS transmission and ways of prevention, they did not use their knowledge to evaluate, moderate, and substantially change their risk behavior. Although there are other studies in line with the above two studies (21, $22)$, there are also a few studies showing an association between knowledge and risk behaviors $(2,23)$.

As previously noted, perceived risk has important and determining role in forming risk behaviors. That means, high perceived HIV risk is known to be associated with less HIV risk behaviors. Several health behavior theories such as $\operatorname{HBM}(4,6,18,24)$, theory of reasoned action (25), theory of planned behavior (26), protection Motivation Theory (27), and the AIDS risk reduction model (28) supported this concept. A meta-analysis of 26 studies examining perceived HIV vulnerability and safer sex behaviors has also confirmed this association (1).

According to these models perception about vulnerability can influence precautionary and protective health behaviors. However, studies have shown that this link exists only when preventive behavior is not complex and negative events with extreme threat are absent. In the other words, perception can influence health and risk behaviors, but under special conditions.

Our findings might have implications for HIV AIDS health education. One approach of HIV health education is provision of factual information, which is pointing to adverse possible consequences of risk behaviors to individuals. This approach was applied by several AIDS campaigns in a number of countries such as Switzerland, Netherlands, and Germany. These health educations communicate facts about AIDS risk, and transmission routes of HIV and recommends protective behaviors or abstinence.

Another approach of HIV education tends to rely on feararousal as a necessary agent for behavioral change. This approach also tends to emphasis negative consequences of not taking preventive actions. Fear-arousal approach was the key element in the early campaigns in the UK. It has been suggested that a drawback of fear-arousal approach is that high levels of fear may lead to denial and reduce the impact of health education. The fear-drive model assumes a curvilinear relationship between fear-arousal and behavior change. The reason for such pattern is that intensive feelings of anxiety can set off defensive reactions such as a failure to pay attention to the health protective messages, rejection of the communication, or defensive avoidance of anxiety-arousing thoughts (13). Coping strategies is a response often used to protect against anxiety and/worry, and might be activated under condition of high stress or treat denial. Although denial reduces emotional distress, it may also reduce likelihood of preventive actions that are necessary to protect health (17). The result of our study also indicated that among people with high perceived HIV risk, HIV knowledge may fail to reduce risky behaviors. This finding might be explained by the above mechanism.

There are at least two main approaches to reduce the burden of HIV/AIDS in the community; treatment and prevention. Preventive strategies use mass media campaigns, condom distribution, peer-education of prostitutes, voluntary counseling and testing, and diagnosis and treatment of other sexually transmitted diseases (29).

Interventions to prevent HIV/AIDS can be grouped into four main categories, including information based approaches, coping skills acquisition, counseling approaches, and contact with affected groups (30). Community-level interventions have improved HIV risk knowledge, enhanced condom use, and increased perceived HIV risk (31). Although we could not find interventions targeting risk behavior of the populations, that have reported interaction between perceived risk and HIV information (32), theory based HIV interventions will influence behaviors through changing perceptions and attitudes $(28,33-35)$.

Our findings may have implications for the development and implementation of HIV prevention programs targeting IDUs in Iran. The findings suggest that HIV prevention programs that primarily emphasize fear-arousal AIDS information will not necessarily increase IDUs' HIV-risk aversion. Although in recent years, policy makers have paid more attention to develop training programs about HIV (36-39), the increasing trend of HIV epidemic shows some problems with these training programs. Although one can not completely deny the current role of media (TV, radio) (39), their role might be increased with a shift in content. Different populations might need benefit from different levels of perceived HIV risk.

Our study has several limitations. Sample size was low. Design was cross sectional. Sampling was not random, thus the results are not generalizable to all Iranian IDUs. Our study did not use standardized inventories to measure HIV knowledge, perceived risk, and sexual behaviors. The study was also limited by only measuring individual level factors (40). 
Despite of the limitations, the study may help us better understand the complex interplay between socio-economic factors, knowledge, attitude, and risk behavior (41-46). Unfortunately, we do not know much about the complex relations between cognition, attitude, and risk behaviors among IDUs. We also do not know how the associations between these psychological constructs vary from one population to another, or from one context to the other. We know that sexual behavior is a complex behavior and is under influence of a long list of variables (47-53).

Promotion of health and wellbeing of general population and HIV risk groups needs research based evidence that can be used to design strategies for health promotion. The same is true for prevention of HIV among IDUs and other HIV risk groups (53-58). It is the collective knowledge - derived from research - that

\section{REFERENCES}

1. Gerrard M, Gibbons FX, Bushman BJ. Relation between perceived vulnerability to HIV and precautionary sexual behavior. Psychol Bull (1996) 119(3):390-409. doi:10.1037/00332909.119.3.390

2. Sowell RL, Seals BF, Phillips KD. Knowledge and risk behaviors of people seeking HIV antibody testing at a community site. J Assoc Nurses AIDS Care (1996) 7(3):33-41. doi: 10.1016/S1055-3290(96)80075-6

3. Tapia-Aguirre V, Arillo-Santillán E, Allen B, Angeles-Llerenas A, CruzValdéz A, Lazcano-Ponce E. Associations among condom use, sexual behavior, and knowledge about HIV/AIDS. A study of 13,293 public school students. Arch Med Res (2004) 35(4):334-43. doi:10.1016/j. arcmed.2004.05.002

4. Strecher VJ, Rosenstock IM. The health belief model. In: Glanze K, Rimer B, editors. Health Behavior and Health Education. San Francisco, CA: Jossey-Bass (1997). p. 41-59.

5. Rosenstock IM, Strecher VJ, Becker $\mathrm{MH}$. Social learning theory and the Health Belief Model. Health Educ Q (1988) 15(2):175-83. doi:10.1177/ 109019818801500203

6. Janz NK, Becker MH. The health belief model: a decade later. Health Educ Q (1984) 11(1):1-47. doi:10. 1177/109019818401100101

7. Rock EM, Ireland M, Resnick MD, McNeely CA. A rose by any other name? Objective knowledge, perceived knowledge, and adolescent male condom use. Pediatrics (2005) 115(3):667-72. doi:10.1542/ peds.2004-0139

8. Lin P, Simoni JM, Zemon V. The health belief model, sexual behaviors, and HIV risk among Taiwanese immigrants. AIDS Educ Prev (2005) 17(5):469-83. doi:10.1521/ aeap.2005.17.5.469
9. Brewer NT, Weinstein ND, Cuite CL, Herrington JE. Risk perception and their relation to risk behavior. Ann Behav Med (2004) 27(2):125-30. doi:10.1207/s15324796abm2702_7

10. van der Pligt J. Perceived risk and vulnerability as predictors of precautionary health behavior. $\mathrm{Br}$ J Health Psychol (1998) 3(1):1-14. doi:10.1111/j.2044-8287.1998. tb00551.x

11. McKenna FP. It won't happen to me: unrealistic optimism or illusion of control? Br J Psychol (1993) 84:39-50. doi:10.1111/j.2044-8295. 1993.tb02461.x

12. Zakay D. The relativity of unrealistic optimism. Acta Psychol (Amst) (1996) 93(1-3):121-31. doi:10. 1016/0001-6918(96)00025-X

13. van der Pligt J, Richard R. Changing adolescents' sexual behavior: perceived risk, self-efficacy and anticipated regret. Patient Educ Couns (1994) 23(3):187-96. doi:10.1016/ 0738-3991(94)90034-5

14. Connors MM. Risk perception, risk taking and risk management among intravenous drug users: implications for AIDS prevention. Soc Sci Med (1992) 34(6):591-601. doi:10. 1016/0277-9536(92)90187-U

15. McCluskey A, Lovarini M. Providing education on evidence-based practice improved knowledge but did not change behaviour: a before and after study. BMC Med Educ (2005) 19(5):40. doi:10.1186/14726920-5-40

16. Lindan C, Allen S, Carael M, Nsengumuremyi F, Van de Perre P, Serufilira A, et al. Knowledge, attitudes, and perceived risk of AIDS among urban Rwandan women: relationship to HIV infection and behavior change. AIDS (1991) 5(8):993-1002. doi:10.1097/ 00002030-199108000-00011

17. van der Pligt J. Risk perception and self protective behavior. Eur

enables policy makers and public health practitioners to prevent blood born infections such as HIV and hepatitis in the community (59-69).

\section{CONCLUSION}

Increasing perceived risk among IDUs does not necessarily result in reduction of risk behaviors. We showed that perceived HIV risk may modify protective effect of HIV knowledge on sexual risk behaviors of IDUs. Further studies, specially using prospective design will be beneficial to understand additive and multiplicative effects of perceived HIV risk and HIV knowledge on HIV risk behaviors. Findings may have implications for media campaigns that use HIV risk communication approach.

Psychol (1996) 1(1):34-43. doi:10. 1027/1016-9040.1.1.34

18. Baron RM, Kenny DA. The moderator-mediator variable distinction in social psychological research: conceptual, strategic, and statistical considerations. J Pers Soc Psychol (1986) 51(6):1173-82. doi:10.1037/0022-3514.51.6.1173

19. Braithwaite K, Thomas VG. HIV/AIDS knowledge, attitudes, and risk-behaviors among African-American and Caribbean college women. Int J Adv Couns (2001) 23:115-29. doi:10.1023/A:1010611328452

20. Salgado de Snyder VN, Díaz Pérez M, Maldonado M. AIDS: risk behaviors among rural Mexican women married to migrant workers in the United States. AIDS Educ Prev (1996) 8(2):134-42.

21. Ferrer L, Cianelli R, Guzman E, Cabieses B, Irarrázabal L, Bernales $\mathrm{M}$, et al. Chilean university students: knowledge and concern about HIV/AIDS. J Assoc Nurses AIDS Care (2007) 18(5):51-6. doi: 10.1016/j.jana.2007.07.001

22. DiClemente RJ, Lanier MM, Horan PF, Lodico M. Comparison of AIDS knowledge, attitudes, and behaviors among incarcerated adolescents and a public school sample in San Francisco. Am J Public Health (1991) 81(5):628-30. doi:10.2105/ AJPH.81.5.628

23. López R, Bravo MJ, Barrio G, Lardelli P, Bueno A, de la Fuente L. HIV-transmission knowledge in drug users from outpatient facilities in Spain. A national survey. Drug Alcohol Depend (1994) 34(3):181-90. doi:10.1016/03768716(94)90155-4

24. Becker MH. The health belief model and personal health behavior. Health Educ Monogr (1974) 2:324-508.
25. Fishbein M, Ajzen I. Belief, Attitude, Intention, and Behavior: An Introduction to Theory and Research. Reading, MA: Addison-Wesley (1975).

26. Ajzen I. The theory of planned behavior. Organ Behav Hum Decis Process (1991) 50:179-211.

27. Rogers RW. A protection motivation theory of fear appeals and attitude change. J Psychol (1975) 91:93-114.

28. Catania JA, Kegeles SM, Coates TJ. Towards an understanding of risk behavior: an AIDS risk reduction model (ARRM). Health Educ Q (1990) 17(1):53-72. doi:10.1177/ 109019819001700107

29. Canning D. The economics of HIV/AIDS in low-income countries: the case for prevention. J Econ Perspect (2006) 20(3):121-42. doi: 10.1257/jep.20.3.121

30. Brown L, MacIntyre K, Trujillo L. Interventions to reduce HIV/AIDS stigma: what have we learned? AIDS Educ Prev (2003) 15(1):49-69. doi: 10.1521/aeap.15.1.49.23844

31. Kelly JA, Murphy DA, Washington CD, Wilson TS, Koob JJ, Davis DR. The effects of HIV/AIDS intervention groups for high-risk women in urban clinics. Am J Public Health (1994) 84(12):1918-22. doi: 10.2105/AJPH.84.12.1918

32. Sikkema KJ, Kelly JA, Winett RA, Solomon LJ, Cargill VA, Roffman $\mathrm{RA}$, et al. Outcomes of a randomized community-level HIV prevention intervention for women living in 18 low-income housing developments. Am J Public Health (2000) 90(1):57-63. doi:10.2105/AJPH.90. 1.57

33. Fisher JD, Fisher WA. Changing AIDS risk behavior. Psychol Bull (1992) 111:455-74. doi:10.1037/ 0033-2909.111.3.455

34. Kelly JA. Changing HIV Risk Behavior: Practical Strategies. New York, NY: Plenum (1995). 
35. Bandura A. Social Foundation of Thought and Action: A Social Cognitive Theory. Englewood Cliffs, NJ: Prentice-Hall (1986).

36. Gupta GR, Weiss E. Women's lives and sex: implications for AIDS prevention. Cult Med Psychiatry (1993) 17(4):399-312. doi:10.1007/ BF01379307

37. Shisana O, Stoker D, Simbayi LC, Orkin M, Bezuidenhout F, Jooste SE, et al. South African national household survey of HIV/AIDS prevalence, behavioural risks and mass media impact - detailed methodology and response rate results. $S$ Afr Med J (2004) 94(4):283-8.

38. Panford S, Nyaney MO, Dip G, Amoah SO, Aidoo NG. Using folk media in HIV/AIDS prevention in rural Ghana. Am J Public Health (2001) 91(10):1559-62. doi:10.2105/AJPH.91.10.1559

39. Bertrand JT, Anhang R. The effectiveness of mass media in changing HIV/AIDS-related behaviour among young people in developing countries. World Health Organ Tech Rep Ser (2006) 938:205-41.

40. Assari S. Multilevel approach to intimate partner violence research and prevention. Int J Prev Med (2013) 4(5):616-7.

41. Angoorani $H$, Narenjiha H, Tayyebi B, Ghassabian A, Ahmadi G, Assari S. Amphetamine use and its associated factors in body builders: a study from Tehran, Iran. Arch Med Sci (2012) 8(2):362-7. doi:10.5114/ aoms.2012.28566

42. Khooshabi K, Forouzan SA, Ghassabian A, Assari S. Is there a gender difference in associates of adolescents' lifetime illicit drug use in Tehran, Iran? Arch Med Sci (2010) 6(3):399-406. doi:10.5114/ aoms.2010.14263

43. Khedmat H, Karami Narenjiha $H$, Rafiey H, Jahani MR, Assari S, Moharamzad Y, et al. Substancedependent professional drivers in Iran: a descriptive study. Traffic Inj Prev (2009) 10(3):227-30. doi:10. 1080/15389580902849017

44. Rafiey H, Narenjiha H, Shirinbayan P, Noori R, Javadipour M, Roshanpajouh $\mathrm{M}$, et al. Needle and syringe sharing among Iranian drug injectors. Harm Reduct J (2009) 6:21. doi:10.1186/1477-7517-6-21

45. Daneshmandan N, Narenjiha H, Tehrani K, Assari S, Khoddami-Vishteh HR. Initiation to the first drug use among substance-dependent persons in Iran. Subst Use Misuse (2011) 46(9):1124-41. doi:10.3109/10826084.2010.490971

46. Alavian SM, Zarchi AAK, Javadipour M, Assari S, Keshvari $M$, Behnava B. Self report cigarette smoking and some correlates in Iranian asymptomatic HBV carriers. Arch Med Sci (2007) 3(3):240-4

47. Kazemi-Saleh D, Pishgou B, Farrokhi F, Assari S, Fotros A, Naseri H. Gender impact on the correlation between sexuality and marital relation quality in patients with coronary artery disease. $J$ Sex Med (2008) 5(9):2100-6. doi:10.1111/j. 1743-6109.2007.00724.x

48. Tavallaii SA, Fathi-Ashtiani A, Nasiri M, Assari S, Maleki P, Einollahi B. Correlation between sexual function and postrenal transplant quality of life: does gender matter? J Sex Med (2007) 4(6):1610-8. doi: 10.1111/j.1743-6109.2007.00565.x

49. Mohammadkhani P, Forouzan AS, Khooshabi KS, Assari S, Lankarani MM. Are the predictors of sexual violence the same as those of nonsexual violence? A gender analysis. J Sex Med (2009) 6(8):2215-23. doi:10.1111/j.1743-6109.2009. 01338.x

50. Mohammadkhani P, Khooshabi KS, Forouzan AS, Azadmehr H, Assari S, Lankarani MM. Associations between coerced anal sex and psychopathology, marital distress and non-sexual violence. J Sex Med (2009) 6(7):1938-46. doi:10.1111/j. 1743-6109.2009.01273.x

51. Kazemi-Saleh D, Pishgoo B, Farrokhi F, Fotros A, Assari S. Sexual function and psychological status among males and females with ischemic heart disease. J Sex Med (2008) 5(10):2330-7.

52. Kazemi-Saleh D, Pishgou B, Assari S, Tavallaii SA. Fear of sexual intercourse in patients with coronary artery disease: a pilot study of associated morbidity. J Sex Med (2007) 4(6):1619-25. doi:10.1111/j. 1743-6109.2007.00619.x

53. Merat S, Rezvan $H$, Nouraie $M$, Jamali A, Assari S, Abolghasemi H, et al. The prevalence of hepatitis $\mathrm{B}$ surface antigen and anti-hepatitis B core antibody in Iran: a populationbased study. Arch Iran Med (2009) 12(3):225-31.

54. Alavian SM, Izadi M, Zare AA, Lankarani MM, Assari S, Vardi MM. Survey of the level of anti-HBs antibody titer in vaccinated Iranian general dentists. Spec Care Dentist
(2008) 28(6):265-70. doi:10.1111/j. 1754-4505.2008.00052.x

55. Ghorbani G, Alavian S, Assari S. Seroepidemiology of hepatitis A virus in Iranian soldiers in 2006: do they need vaccination? Hepat Mon (2007) 7(1):7-9.

56. Ghorbani GA, Alavian SM, Esfahani AA, Assari S. Seroepidemiology of hepatitis $\mathrm{E}$ virus in Iranian soldiers. Hepat Mon (2007) 7(3):123-6.

57. Behnava B, Assari S, Amini M, Hajibeigi B, Manzouri Jouybari $\mathrm{H}$, Alavian SM. HBV DNA viral load and chronic hepatitis infection in different stages. Hepat Mon (2005) 5(4):123-7.

58. Alavian SM, Mansouri S, Abouzari M, Assari S, Bonab MS, Miri SM. Long-term efficacy of hepatitis B vaccination in healthcare workers of Oil Company Hospital, Tehran, Iran (1989-2005). Eur J Gastroenterol Hepatol (2008) 20(2):131-4. doi:10. 1097/MEG.0b013e3282f1cc28

59. Haghdoost A, Karamouzian M. Zero new HIV infections, zero discrimination, and zero AIDS-related deaths: feasible goals or ambitious visions on the occasion of the world AIDS day? Int J Prev Med (2012) 3(12):819-23. doi:10.4103/ 2008-7802.104850

60. Alavian SM. On the occasion of the world hepatitis day: world hepatitis day and our achievements and responsibilities in Iran. Int J Prev Med (2012) 3(7):437-9.

61. Hassannejad R, Kassaian N, Ataei B, Adibi P. High risky behaviors among intravenous drug users in Isfahan, Iran: a study for hepatitis $\mathrm{C}$ harm reduction programs. Int J Prev Med (2012) 3(Suppl 1):S73-8.

62. Nokhodian Z, Meshkati M, Adibi P, Ataei B, Kassaian N, Yaran M, et al. Hepatitis $\mathrm{C}$ among intravenous drug users in Isfahan, Iran: a study of seroprevalence and risk factors. Int J Prev Med (2012) 3(Suppl 1):S131-8.

63. Assari S, Jafari M. Quality of life and drug abuse. In: Preedy VR, Watson $\mathrm{RR}$, editors. Handbook of Disease Burdens and Quality of Life Measures. Heidelberg: Springer (2010). p. 3691-704.

64. Azizabadi Farahani M, Assari S. Quality of life and sexuality. In: Preedy VR, Watson RR, editors. Handbook of Disease Burdens and Quality of Life Measures. Heidelberg: Springer (2010). p. 3457-73.

65. Noroozi M, Nedjat S, Golestan B, Majdzadeh R. What are differences between non-injecting and injecting drug addicts? Int J Prev Med (2012) 3(6):414-9.

66. Kassaian N, Adibi P, Kafashaian A, Yaran M, Nokhodian Z, Shoaei P, et al. Hepatitis $C$ virus and associated risk factors among prison inmates with history of drug injection in Isfahan, Iran. Int J Prev Med (2012) 3(Suppl 1):S156-61.

67. Shokoohi M, Baneshi MR, Haghdoost AA. Size estimation of groups at high risk of HIV/AIDS using network scale up in Kerman, Iran. Int J Prev Med (2012) 3(7):471-6.

68. Nobari RF, Meshkati M, Ataei B, Yazdani MR, Heidari K, Kassaian $\mathrm{N}$, et al. Identification of patients with hepatitis $\mathrm{C}$ virus infection in persons with background of intravenous drug use: the first community announcement-based study from Iran. Int J Prev Med (2012) 3(Suppl 1):S170-5.

69. Nasrullah M. Concentrated HIV epidemic in Pakistan: an opportunity to prevent generalized epidemic. Int $J$ Prev Med (2012) 3(12):824-6. doi:10.4103/2008-7802.104851

Conflict of Interest Statement: The authors declare that the research was conducted in the absence of any commercial or financial relationships that could be construed as a potential conflict of interest.

Received: 09 August 2013; paper pending published: 12 August 2013; accepted: 28 August 2013; published online: 30 September 2013.

Citation: Noroozinejad G, Yarmohmmadi Vasel M, Bazrafkan F, Sehat $M$, Rezazadeh M and Ahmadi K (2013) Perceived risk modifies the effect of HIV knowledge on sexual risk behaviors. Front. Public Health 1:33. doi: 10.3389/fpubh.2013.00033

This article was submitted to HIV and AIDS, a section of the journal Frontiers in Public Health.

Copyright (c) 2013 Noroozinejad, Yarmohmmadi Vasel, Bazrafkan, Sehat, Rezazadeh and Ahmadi. This is an open-access article distributed under the terms of the Creative Commons Attribution License (CC BY). The use, distribution or reproduction in other forums is permitted, provided the original author(s) or licensor are credited and that the original publication in this journal is cited, in accordance with accepted academic practice. No use, distribution or reproduction is permitted which does not comply with these terms. 